\title{
OBSERVATIONS ON INSECTS' BEHAVIOR IN ATTACKING WOOD
}

\author{
Hamed, S. \\ Conservation dept., Faculty of Archaeology, Cairo Univ., Giza, Egypt \\ E-mail:Safa_an78@yahoo.com
}

\begin{abstract}
Insect attack is a major problem to wood generally, whether it was shaped in objects or in structures. Thus, the present study aims to highlight the behavior of insects while attacking the wood. It also aims to study the effect of preparation layers as well as coating and consolidation materials' presence on wood-destroying insects' behavior. Eleven samples were selected among numerous infected wood for investigation and examination by the Environmental Scanning Electron Microscope (ESEM). Moreover, Fourier-Transform Infrared Spectroscopy (FTIR) was used to identify the materials employed in previous treatments. The chemical composition of the preparation layers applied on the wood surface was analyzed by X-Ray Diffraction (XRD). Then, the results of the different samples were compared. The SEM examination suggested that there are different insect behaviors in attacking wood according to its status, i.e. covered with preparation layers, coated, or consolidated. It is quite evident from the obtained results that bare wood is the most affected, whereas the loss was reduced in wood samples covered with chalkpreparation layers. Furthermore, Paraloid B72 enhances hardwoods protection against reinfestation.
\end{abstract}

Keywords: Hardwoods, Insect attack, Consolidants, Preparation layers, SEM

\section{Introduction}

Insects are the most serious pests attacking wood since they use wood for food, shelter, and breeding [1]. Additionally, some insects excavate nests in wood but do not use them [2]. Although many insects destroy wood, the most common manifestations are caused by the orders Coleoptera (beetles) and Isoptera (termites) [3]. Wood-inhabiting beetles can invade and damage wood furniture as well as structural and decorative wood in the buildings [4]. These beetles are of particular concern in structures because they can breed in (re-infest) wood in use [5]. Moreover, insect attacks cause disintegration and removal of substantial quantities of the wood substance, leading to macroscopically visible changes [2]. Beetles are numerous and extremely varied in terms of general appearance and feeding habits. They differ in adult appearance, size of exit holes, and frass characteristics. Furthermore, insect species differ in their preference for wood; while some insects attack only hardwoods, others attack softwoods only, and another group attacks both. Additionally, using wood carbohydrates differs among insect species. Some of them can metabolize only readily soluble sugars, while others depend on wood starches [1]. Meanwhile, the nutritive content of the wood and the surrounding environmental conditions, notably the temperature and relative humidity; greatly affect the life cycle of the beetles [6]. Wood-destroying insects use their abilities of astounding sensory discrimination to choose the appropriate location 
for laying eggs. The material's condition and certain wood constituents have an important role in laying and placing of eggs [1]. Powder post beetles only lay their eggs on the bare wood. However, the placement site differs between the beetle species. Some species lay eggs in cracks, crevices, or exit holes that can be found on the wood surface, while others insert their eggs in the wood pores. According to the species, the exit hole may be made by the adult or by the fullgrown larva [7]. The main concern of insect attack that signs the infestation are not often seen until the wood is destroyed and adults begin to emerge. Hence, insects can turn the infested wood into powder with leaving only a thin crust of wood on the surface. Therefore, structural failure in timber can take place due to the extensive infestation [8], whereas a re-

\section{Materials and Methods}

\subsection{Wood samples}

Various samples were collected from infected hardwoods from different places that had been exposed to insect attacks. Some of them were coated, while others underwent previous repairs. Lots of samples were friable and were therefore difficult to examine. Moreover, eleven samples were chosen for studying insects' behavior while attacking wood. Four samples were taken from different wooden objects from the $1^{\text {st }}$ dynasty's tombs from the excavations of the Supreme Council of Antiquities in Saqqara (2003-2004)

\subsection{Environmental scanning electron microscope}

The infected wooden samples were examined using ESEM (Quanta 250 FEG and Philips XL 30). They were fixed on

\subsection{FTIR spectroscopic analysis}

The materials used in previous treatments for consolidation or coating were analyzed with a Cary 630 FTIR spectrometer, using $\mathrm{KBr}$ method and representing

\subsection{X-Ray diffraction (XRD)}

The mineral composition and its percentage in the preparation layers applied on the surface of some samples were determined using a Philips X-ray diffracto- cent study has proved that the degraded wood continues to have a reasonable carrying capacity [9]. The exact identification of insect species requires examination of adults or larvae [10]. However, this is not often achievable and requires recourse to using external and internal characteristics of damaged wood. Factors like exit holes and their shape, size, and condition on the wood surface as well as the location and course of tunnels often restrict the responsibility on certain species. Moreover, the preference for certain wood species already has a diagnostic value [1]. This study investigates the behavior of insects attacking wood. It also examines how the presence of preparation layers, coating and consolidation materials affect wood-destroying insects' behavior. Consequently, this helps improve the pestmanagement programs.

and two of them were covered with a gesso layer. Four samples of turned wood were taken from the Cavern church - Abu Serga, Bayt Al Razzaz's Mashrabiya, Radwan baik's Maqaad, and an anonymous Mashrabiya stored at the conservation department, faculty of archaeology, Cairo Univ. Aso, one sample from a polychrome wooden Graeco-Roman coffin and two samples from wooden objects stored in the museum storage at the faculty of archaeology were obtained, as well.

aluminum stubs with double-sided cellophane tape. After that, they were examined.

$(2 \mathrm{~mm} / \mathrm{Sec})$ co-added scans at the spectral region ranging from $400 \mathrm{~cm}^{-1}$ to $4000 \mathrm{~cm}^{-1}$.

meter (type PW 1480, giving $40 \mathrm{kV} \mathrm{Cu}$ $\mathrm{Ka}$ radiation at $25 \mathrm{~mA}$ ). The peaks were determined and measured using Match 3 + PDF4 2015 software program. 


\section{Results}

SEM examination showed that all investigated samples were identified as hardwoods owing to the existence of the vessel cells which represent their main feature. Beetles were the dominant ins-

\subsection{Bare wooden samples}

The progressive loss was noticed in the wood structure of the bare wooden samples, fig. (1-a,b,c) especially in vessels as seen in sample no. 1. This may be due to the fact that eggs are often laid down in vessel cells. Thus, these cells are the most affected parts. Interestingly, these samples exhibited differences in the ects in this study according to the egg shape and the frass found in some emergence holes. Dramatic differences in wood consumption between the infected samples were detected, as follows:

wood damage since sample no. 3 was the most affected. Structure deformation and the total collapse were apparent in sample no. 3, whereas the other two samples still have the general arrangement of cells in spite of the extensive erosion and losing parts of the structure.
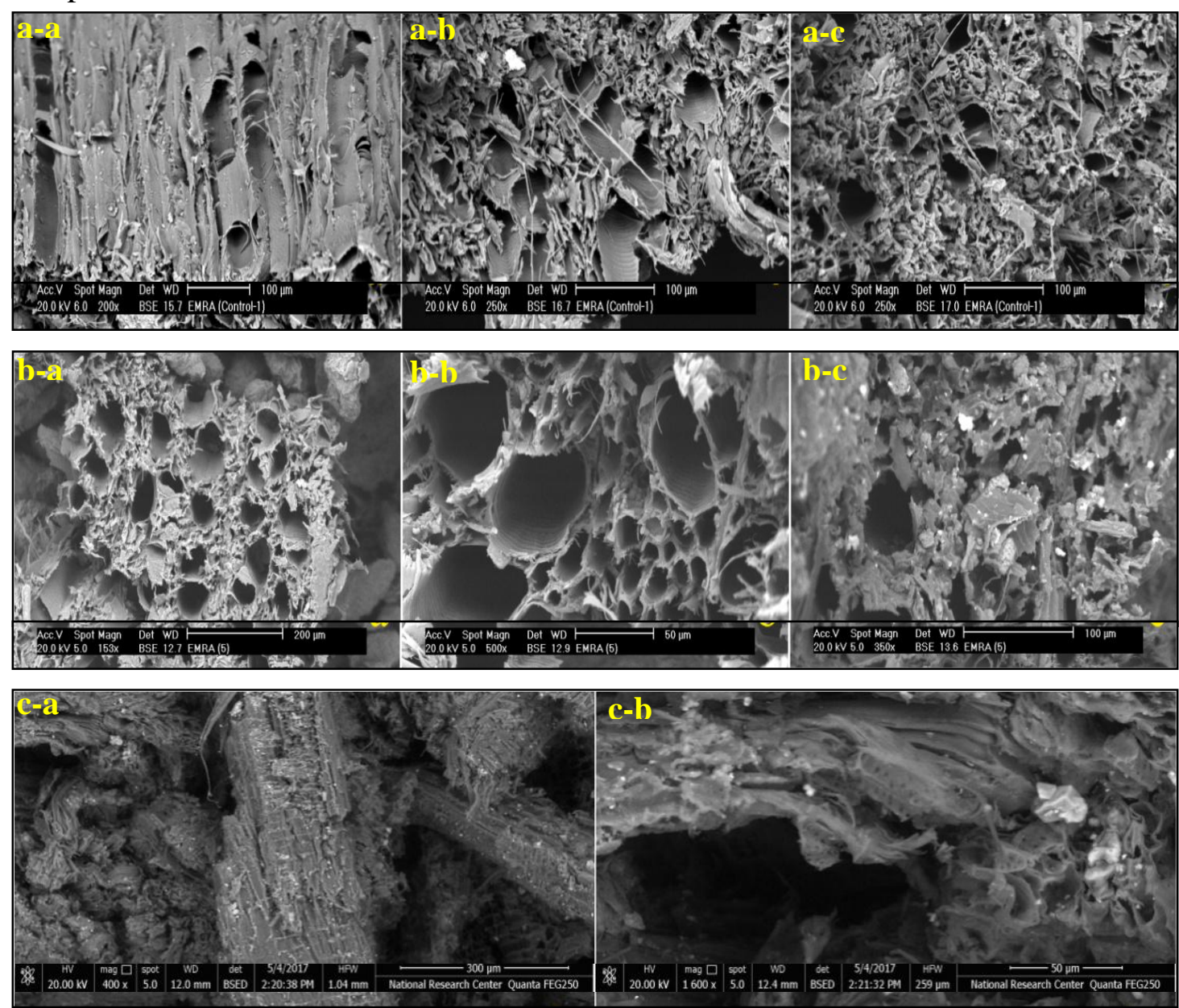

Figure (1) Shows SEM photomicrographs of (Sample 1); the bare wooden samples; $\underline{\mathbf{a}}$-a. . erosion of cells notably vessels, $\underline{\mathbf{a}}-\underline{\mathbf{b}} . \mathbf{\text { . }} \& \underline{\mathbf{a}}-\mathbf{c}$. the consumption that took place in wood structure. (Sample 2); the bare wooden samples $\underline{\mathbf{b}}-\underline{\mathbf{a}}$. losing parts of the wood structure, $\underline{\mathbf{b}}-\underline{\mathbf{b}}$. \& $\underline{\mathbf{b}}-\underline{\mathbf{c}}$.

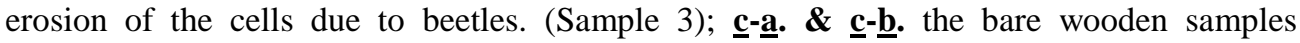
structure deformation and the total collapse of wood

\subsection{Wooden samples coated with preparation layers}

The preparation layers that were applied on the wood surface in some samples composed primarily of calcium carbonate (calcite), as shown by XRD results, fig. (2-a). In addition, the micrographs of these samples $(2-b, c, d)$ revealed the presence of the insect attack, but the damage is much lesser than the bare wood. Addi- 
tionally, the loss of the wood cells is more apparent in sample no. 5, fig. (2c), in spite of the loss that took place near the preparation layer in sample no. 6 , fig. (2-d). This may be interpreted as this area was next to the emergence hole.
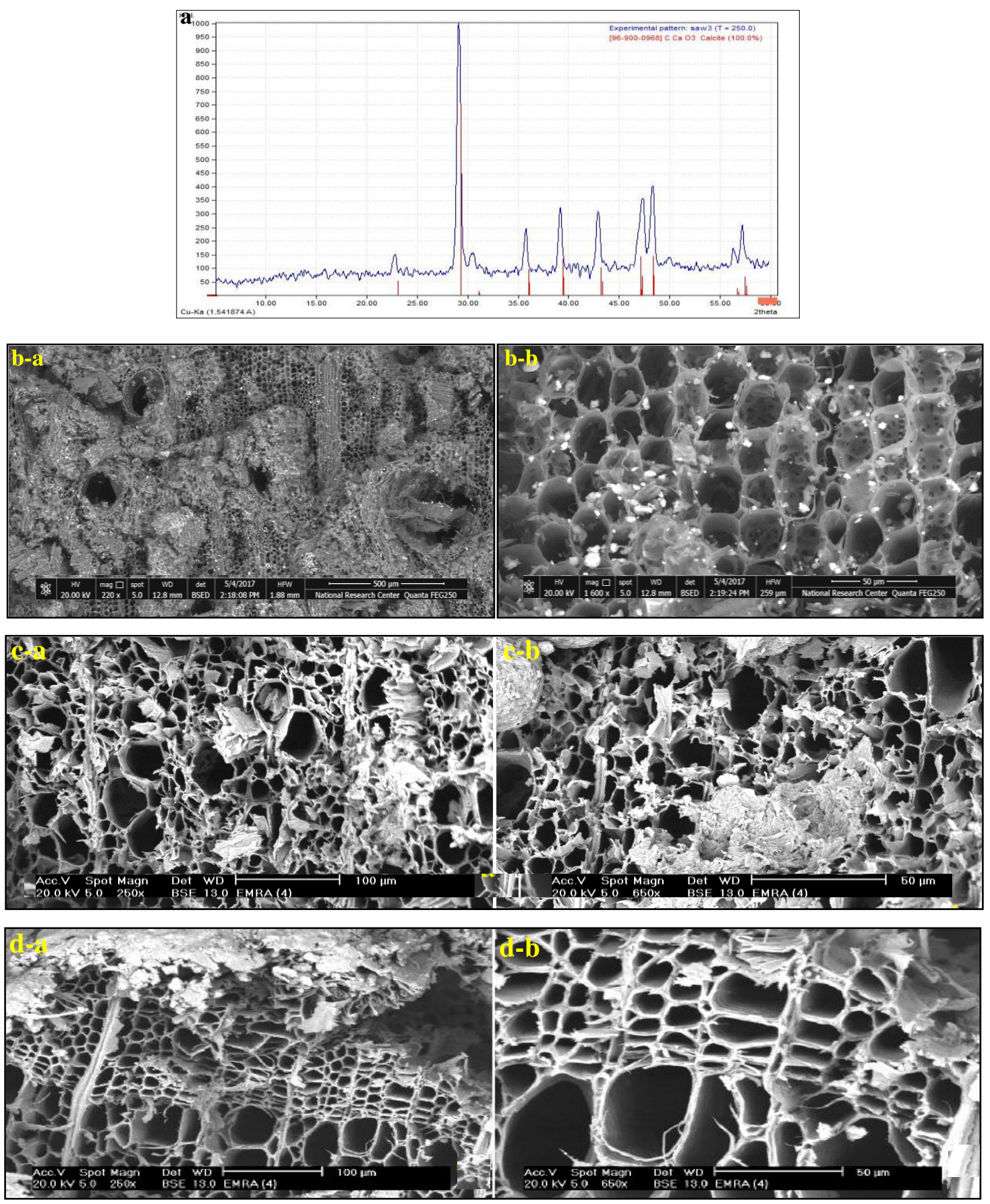

Figure (2) Shows $\underline{\mathbf{a}}$. X-ray diffraction pattern of preparation layers applied on some samples surface, $\underline{\mathbf{b}}-$

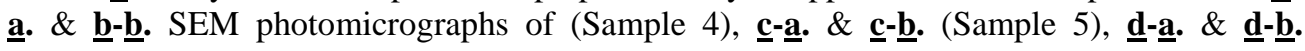
(Sample 6) which are coated with preparation layers,

\subsection{Wooden samples consolidated with synthesis materials}

As shown by the SEM results, the foreign resinous materials covered the wood structure. They were applied on the wood in a previous intervention. FTIR results identify these materials as Paraloid B72, fig. (3-a) according to the appearance of its characteristic bands at $2934-2861 \mathrm{~cm}^{-1}, 1727 \mathrm{~cm}^{-1}, 1370-1430$ $\mathrm{cm}^{-1}$ and 1020-1228 $\mathrm{cm}^{-1}$ [11]. Notably, samples no. 7, fig. (3-b,c) 8, fig. (3-d,e) and 9 , fig. (3-f,g) exhibited extensive degradation due to insect attack. The eggs 
clusters could be seen within the wood structure. The accumu-lation of Paraloid B72 on the wood cells could be observed in sample no. 10 fig. (3-h,i) and 11, fig. $(3-\mathrm{j}, \mathrm{k})$ with erosion signs due to the insect attack.
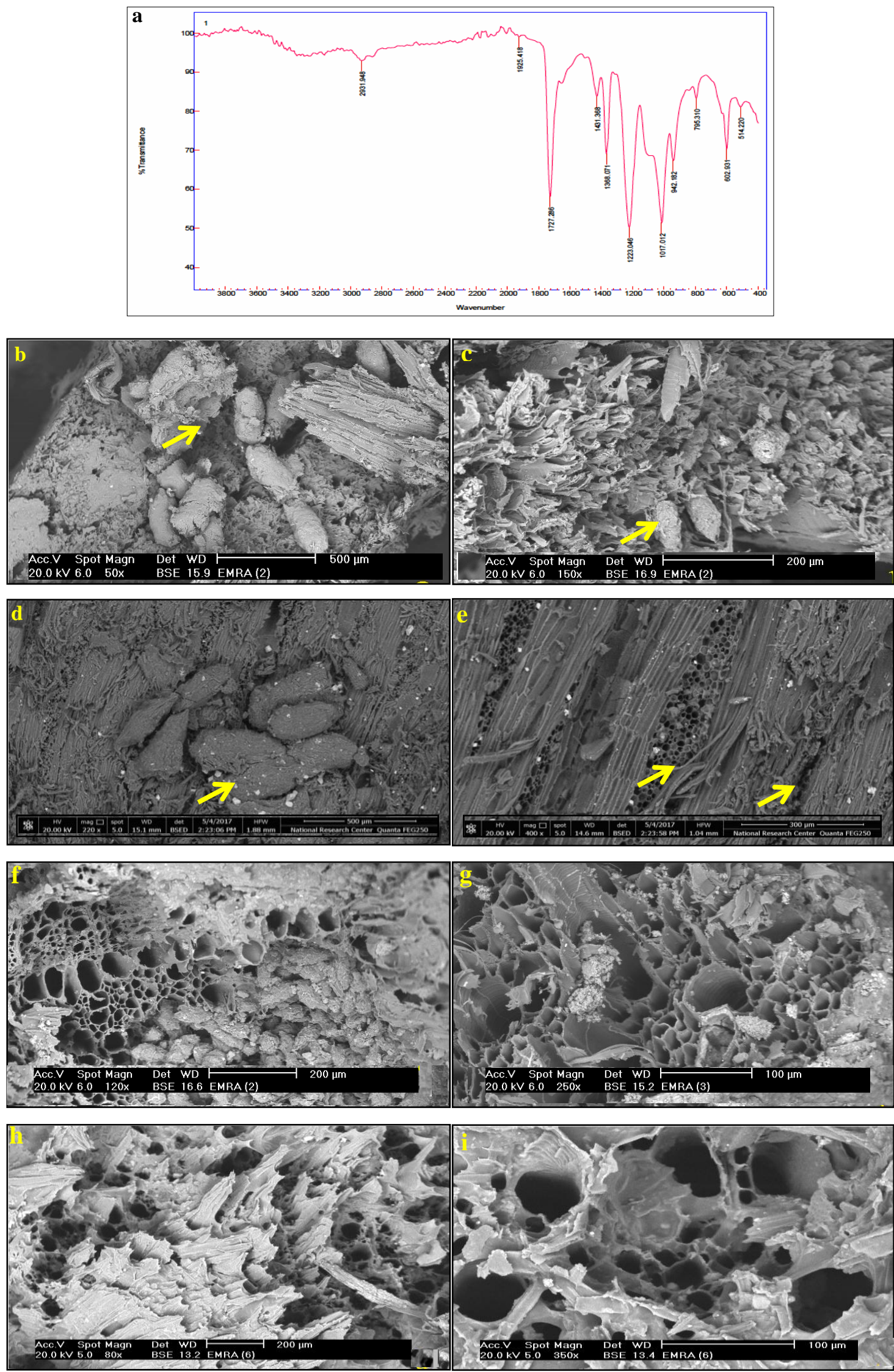


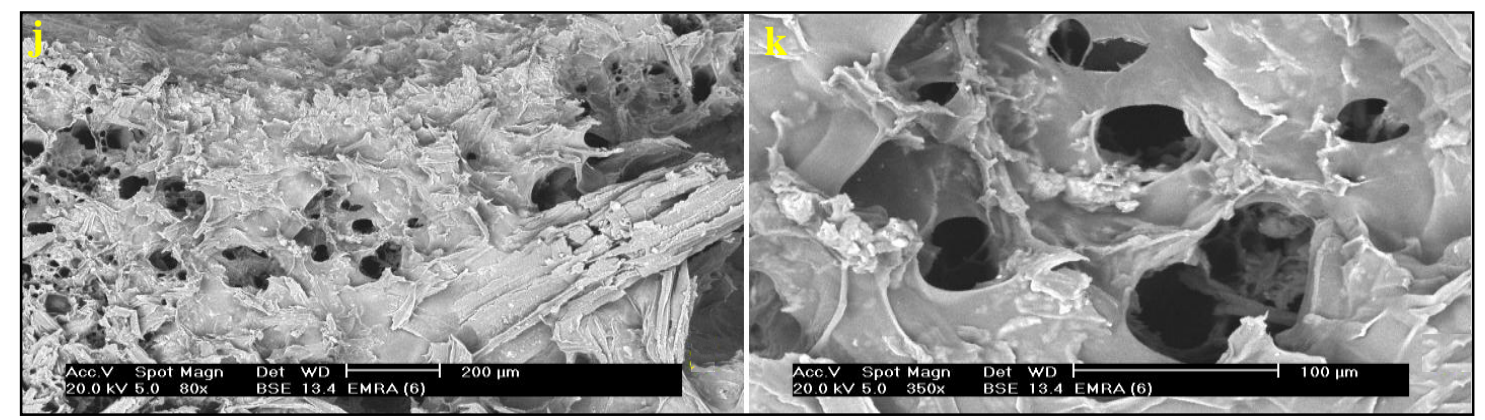

Figure (2) Shows ‥ FTIR spectra of the consolidant that have been used in the previous restoration, $\underline{\mathbf{b}}$. \& c. SEM photomicrographs of treated samples; (Sample 7) presence of insect's eggs especially in vessels as seen in, $\underline{\mathbf{d}}$. (Sample 8) the insect's eggs, $\underline{\mathbf{e}}$. erosion of the cells especially vessels, $\underline{\mathbf{f}}$. (Sample 9) the clusters of eggs, g. erosion and deformation of the cells, h. \& i. (Sample 10) decaying features due to insect attack without any signs on their presence except for the resulting erosion, $\mathbf{j}$. \& $\underline{\mathbf{k}}$. (Sample 11) consolidant covering the wood surface entirely in some parts of the structure without any evidence on the insect presence

\section{Discussion}

Differences in laying and placement of eggs within the wood structure or inside the pores indicate that the chosen samples were infested by different species of beetles [7]. Moreover, variance in the amount of damage between bare wooden samples might be explained by several variables. First, the length of infestation period played a role. Second, the starch content, which is important for insects' feeding, varied widely according to the hardwood species, the conditions of their growth and the natural fluctuations [12, 13]. Moreover, the starch content is thought to have an important effect on the differences in the consumption rate between wood species. Third, this may be related to the vessel diameter which has a relationship with the diameter of the insect's ovipositor [14]. Finally, wood density which had an influence on the amount of damage in the wood structure $[15,16]$. The occurrence of insect attack in the wood covered with preparation layers may violate what was reported before that insects never deposited their eggs in polished, waxed, varnished, or painted surfaces [17]. Similarly, Ackroyd stated that gesso layers are considered one of the protective coatings that provide a deterrent against insect infestation [18]. On the contrary, it was proven that wooddestroying beetles can bore their way through rigid and undesirable layers in order to reach the interior zones of the objects which contain their food source [1]. However, the amount of damage was reduced in the samples covered with chalkbased preparation layers. This finding assumes that beetles do not prefer the alkaline environment. It can match what has been reported by Sajan [19] that the digestive enzymes in insects would be much less active under the alkaline conditions. Paraloid B72 is the most employed consolidant material for degraded wood, particularly for wood exposed to biological attack [20]. The existence of eggs clusters reflects the extent of the infestation and indicates that the consolidation process was done during the stages of insect infestation. The life cycle of the insect had stopped as a result of applying Paraloid B72 to consolidate the wood. Moreover, the accumulation of Paraloid B72 on samples no. 10 and 11 without observing any remnants of the insect infestation, i.e. eggs, larvae, wings, except the previous damage, suggests that the consolidation may have eliminated infestation. These results support that the finding that Paraloid B72 provides partial resistance to consolidated wood against insect infestation $[1,21,22]$. In general, this study suggests that despite these variations, beetles use and consume the bare wood preferably. In contrast, they avoid attacking wood covered with protective coatings or 
consolidants except for necessity, where they bore through these layers to reach their food. The study was limited by the great difficulty in getting appropriate samples because insect attacks damage the wood structure in some cases entirely or even leave the samples too friable to be examined. Hence, only eleven samples were chosen for studying insects' behavior in attacking wood. The chosen samples were examined at different periods. As a result, two versions of ESEM were utilized.

\section{Conclusion}

Attacking beetles to susceptible hardwoods is occasionally inevitable. The micrographs showed differences in insects' preference for attacking wood between wooden samples. However, the amount of consumed wood depends on the beetle species and the wood species. This can be interpreted by the fact that beetles' susceptibility to attack wood is governed by four variables: starch content, vessels diameter, wood density, and moisture content. Additionally, the chalkbased preparation layers play a role in reducing the consumption of wood, whereas Paraloid B72 provides some protection to the consolidated wood against re-infestation by insects. Further works shall be done to study the relation between the different species of beetles and their feeding preference for the hardwood species.

\section{References:}

[1] Unger, A., Schniewind, A. \& Unger, W., (2001). Conservation of wood artifacts, Springer-Verlag Berlin Heidelberg, Germany.

[2] Nilsson, T. \& Daniel, G., (1990). Structure and the aging process of dry archaeological wood", in: Rowell, R. \& Barbour R. (eds.) Archaeological Wood: Properties, Chemistry and Preservation, American Chemical Society, Washington D.C., pp: 81-83.

[3] Shupe, T., Lebow, S. \& Ring, D., (2008). Causes and control of wood decay, degradation and stain, Louisiana Cooperative Extension Service2703, Agricultural Center, Louisiana State Univ., 26 p.

[4] Kaygin A., (2007). Industrial wood destroying insects, $1^{\text {st }}$ ed., Nobel Pub. No: 1082, Science and Biology Pub. Series, No. 31, Ankara, 243.

[5] Morris, P., (1998). Understanding biodeterioration of wood in structures, Research report, Forintek Canada Corp, Vancouver, BC.

[6] Eaton, R. \& Hale, M., (1993). Wood: Decay pests and protection, Chapman and Hall, London.

[7] Jones, S., (2008). Powder post beetles, Fact sheet, Agriculture and natural resources, The Ohio State Univ, USA, $5 \mathrm{p}$.
[8] Akcay, C., Yalcin, M., Tascioglu, C., Büyüksar, Ü. \& Menderes, C., (2017). Survey studies of the Anobiidae and Lyctidae families (Coleoptera) in wood depots and wood factories of some provinces in Turkey, J. of Advanced Technology Sciences, Vol. (3), pp: 1048-1052

[9] Mendes, S., Henriques, D. \& Alves, M., (2018). Propriedades mecânicas de madeira degradada por caruncho em edifícios antigos: uma análise experimental, Conservar Património, Vol. 28, pp: 23-29

[10] Florian, M., (1997). Heritage eaters. Insects and fungi in heritage collections, James \& James, London.

[11] Derrick, R., Stulik, D. \& Landy, M., (1999). Infrared spectroscopy in conservation science. The Getty Conservation Institute, Los Angeles.

[12] Campbell, W., Frahn, J., Hirst, E., Packman, D. \& Percival, E., (1951). Wood starches, Part I, J. of the chemical society, Vol. 1951, pp: 3489-3498

[13] Peters, B., Creffield, J., Eldridge, R., (2002). Lyctine (Coleoptera: Bostrichidae) pests of timber in Australia: A literature review and susceptibility testing protocol, Australian Forestry, Vol. 65 (2), pp: 107-119 
[14] Bamber, R. \& Erskine, R., (1965). Relationship of vessel diameter to Lyctus susceptibility in some New South Wales hardwoods, Research notes No. 15, Forestry Commission of N. S. W., Sydney.

[15] Peralta, R., Menezes, E., Carvalho, A. \& Aguiar-Menezes, E., (2004). Wood consumption rates of forest species by subterranean termites (Isoptera) under field conditions. Revista Árvore., Vol. 28 (2), pp: 1-12.

[16] Arango, R., Green, F., Hintz, K., Lebow, P. \& Miller, R., (2006). Natural durability of tropical and native woods against termite damage by Reticulitermes flavipes (Kollar). Int. Biodeterioration Biodegradation, Vol. 57, pp: 146-150.

[17] Gerberg, E., (1957). A revision of the new world species of powder-post beetles belonging to the family Lyctidae, USDA Technical Bulletin, Vol. 1157, pp: 14-55.

[18] Ackroyd, P., (2012). The structural conservation of paintings on wooden panel supports, in: Stoner, J. \& Rus- hfield, R. (eds.), Conservation of easel paintings, Routledge, NY, pp: 453478.

[19] Sajan, K.S., (2002). Studies on the protease activity in the digestive system of iphita limbata (Heteroptera: Pyrrhocoridae), PhD, Zoology dept., University of Calicut, Kerala, India.

[20] Cataldi, A., (2015). Micro and nanostructured polymeric materials for art protection and restoration, $\mathrm{PhD}$ Industrial Engineering dept., Materials Science and engineering School, University of Trento, Italy.

[21] Unger, A., Schniewind, A., \& Unger, W., (1998). Conservation of wood artifacts, Springer-Verlag, Berlin.

[22] Muhcu, D., Terzi, E., Kartal, S. \& Yoshimura, T., (2017). Biological performance, water absorption, and swelling of wood treated with nanoparticles combined with the application of paraloid B72, J. of Forestry Research, Vol. 28 (2), pp: 381-394. 